\author{
Agnieszka Sosnowska \\ University of Warsaw \\ Faculty of Geography and Regional Studies \\ Department of Geoecology \\ e-mail: ajsosnowska@gmail.com
}

\title{
ISSUES OF SECONDARY SUCCESSION IN THE SUBALPINE FOREST GLADES OF THE CARPATHIAN MOUNTAINS. (CASE STUDY)
}

\begin{abstract}
Results of research on the process of spontaneous overgrowth of subalpine forest glades in the Gorce National Park are presented in the paper. Research was carried out in 2006-2008. The condition and directions of changes of glades undergoing conservation efforts of different intensity were examined.
\end{abstract}

Key words: secondary succession, Carpathian Mountains, Gorce National Park, subalpine forest glades, environmental protection, non-forest ecosystems.

\section{INTRODUCTION}

Non-forest ecosystems located in the area of the upper and lower subalpine glades in the Carpathian Mountains constitute semi-natural communities. In consequence of tree cutting which has been taking place over centuries, forest burning, sheep and cattle grazing as well as grass cutting, man has created subalpine forest glades.

Pastoral economy in the Carpathian Mountains goes back to the $14^{\text {th }}$ century. Its beginnings are associated with the Vlach nomadic shepherd tribes which came into the Gorce and Pieniny region from the Balkans. In the beginning of mid- $15^{\text {th }}$ century nomadism began to disappear. This was caused by the development of first permanent human settlements at mountain bases. Shepherds only were staying in the mountains from summer till autumn and then moved together with their stock to households situated in permanent settlements. Construction of shepherd sheds and numerous religious cult facilities in glades was associated with seasonal nomadism. The most dynamic development of shepherding took place at the turn of the $18^{\text {th }}$ and $19^{\text {th }}$ centuries. Both great quantities of firewood and substantial 
stretches of land for cultivation and grazing originated in numerous felling sites in the area. Legal regulations constraining forest felling were implemented late in the $19^{\text {th }}$ century. At that time, the Tatra Mountains were the largest grazing area (by number of cattle head). They were followed by the Gorce, Bieszczady and Pieniny Mountains (Michalik, 1998).

In the second decade of the $20^{\text {th }}$ century, there was a drastic reduction in the number of grazing cattle and sheep. This was caused by the diminishing profitability. At that time, in Poland, dynamic changes were taking place in agriculture. Numerous farmers retrained and took up jobs in newly developing branches of industry. Following World War II, cattle and sheep grazing were almost totally abandoned in the Carpathian Mountains. This was mainly caused by an economic transformation as well as the nationalization of forests and implementation of legal regulations on forest management. Abandoning use of subalpine forest glades initiated spontaneous processes of secondary succession. Surveillance of this phenomenon, beginning in the sixties of the $20^{\text {th }}$ century, is chiefly carried out by biologists (Michalik, 1992, 1995) and foresters (Ciurzyński, 2004c, 2005).

The aim of this research is to identify changes which are taking place in non-forest ecosystems in the Gorce National Park, depending on the conservation actions being undertaken. An effort has also been made to identify a trend in the changes taking place in the examined ecosystems. Results were compared with the results of other authors.

\section{RESEARCH AREA AND METHODS}

Research was carried out in the Gorce National Park in 2006-2008. It comprised of analysis of cartographic materials (maps made by Stefan Jarosz (1935), topographic maps from 1965 and orthophotomaps from 2003) as well as an observation of changes in the biocoenosis and landscape in the area. Observations were carried out four times, i.e. in May 2007, August 2007, December 2007 and April 2008, on four of the hundred and ten glades. Three subalpine forest glades were chosen for detailed analysis. They include Hala Wzorowa, Polana Jaworzyna Kamienicka and Hala Młyńskie. The criterion for selection of the research grounds included the kind and intensity of the conservation activities being implemented. Cultural sheep grazing is carried out in Hala Wzorowa, whereas in the other areas, grazing has ceased a dozen or more years ago. Currently, the area is being mowed. Polana Jaworzyna Kamienicka is being mowed once every $2-3$ years, while Hala Młyńskie - once every 5 years. Seedlings and brushwood are also removed from the glades, maintaining the permanent location of the forest zone. Additional observation was carried out in the area of glades which do not come under active conservation. 


\section{RESEARCH RESULTS}

\section{Hala Wzorowa}

In the period of analysis being held the area of the glade has not undergone any changes. There is also a lack of visible floristic changes. Fertile gladiolus-bent grass (Gladiolo-Agrostietum) meadows, growing in several variations, dominate. Spreading of bilberries (Vaccinium myrtillus) and wild raspberries (Rubus idaeus), which is the last phase of transformation of non-forest ecosystems in forests, is not observed (Photo no.1).

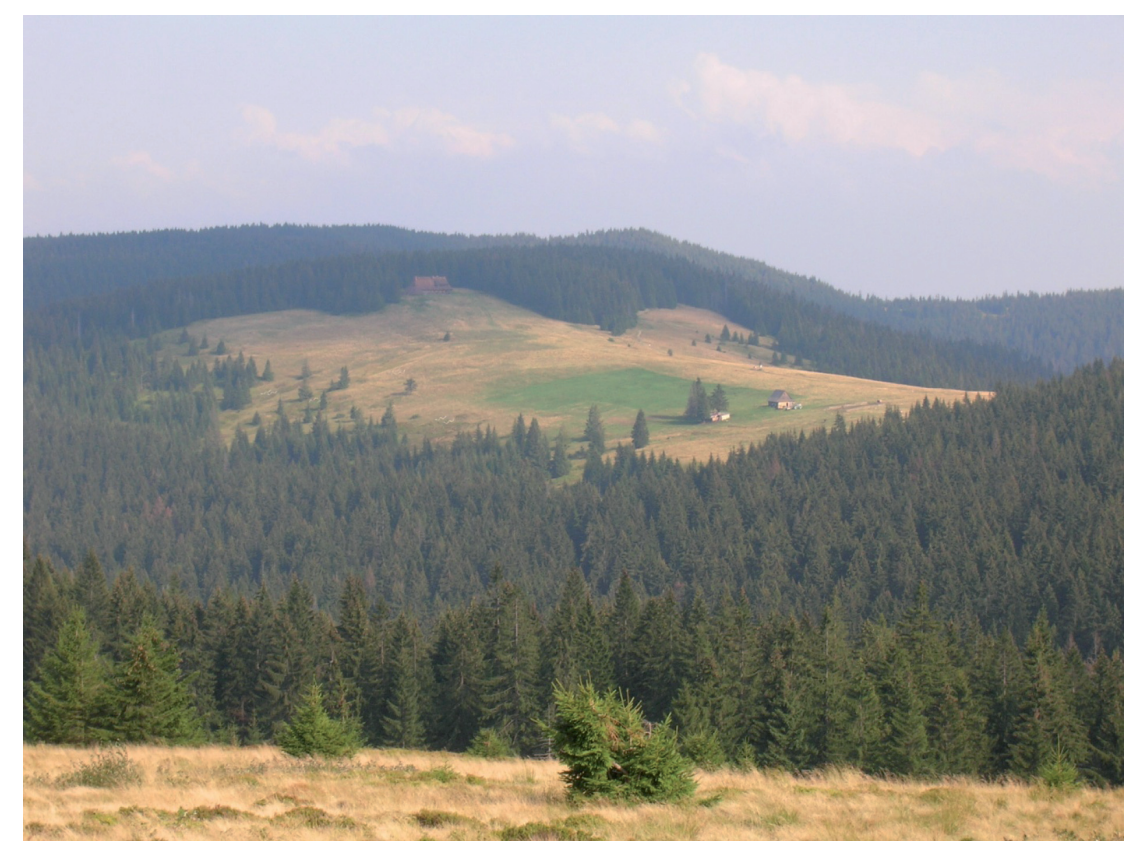

Photo no. 1. Hala Wzorowa (photo by A.Sosnowska)

\section{Jaworzyna Kamienicka Glade}

In the period of analysis being held the surface of the glade has undergone changes. A decrease in the area has been observed in places not included in the conservation activities. The glade is characterized by a lesser degree of preserved plant communities than it is observed in Hala Wzorowa. Foremost, impoverished matgrass (Hieracio-Nardetum) grow there, which is the second phase of succession in transformation of the fertile gladiolus-bent grass (Gladiolo-Agrostietum) meadows as a result of soil impoverishment caused by lack of nourishing elements and non-forest elements of non-defined fitosociological affiliation, being in various phases of transformation as a result 
of secondary succession. A significant area of the glade is occupied by bilberries (Vaccinium myrtillii) and wild raspberries (Rubus idaeus) and spruce trees (Picea abies), growing singly or in bio-groups. Fragments subject to active conservation are characterized by a higher degree of retention of plant communities. For this reason, they have been bought by the Park's management from private citizens. Bilberries (Vaccinium myrtillii) spread into the area not included in the conservation activities, from the side of the forest wall and head-streams. This allows for expansion of spruce trees (Picea abies) and in consequence, diminishes the size of the glade (Photo no.2). Analogical changes were observed in other glades that are partially property of the Gorce National Park or do not belong to it.

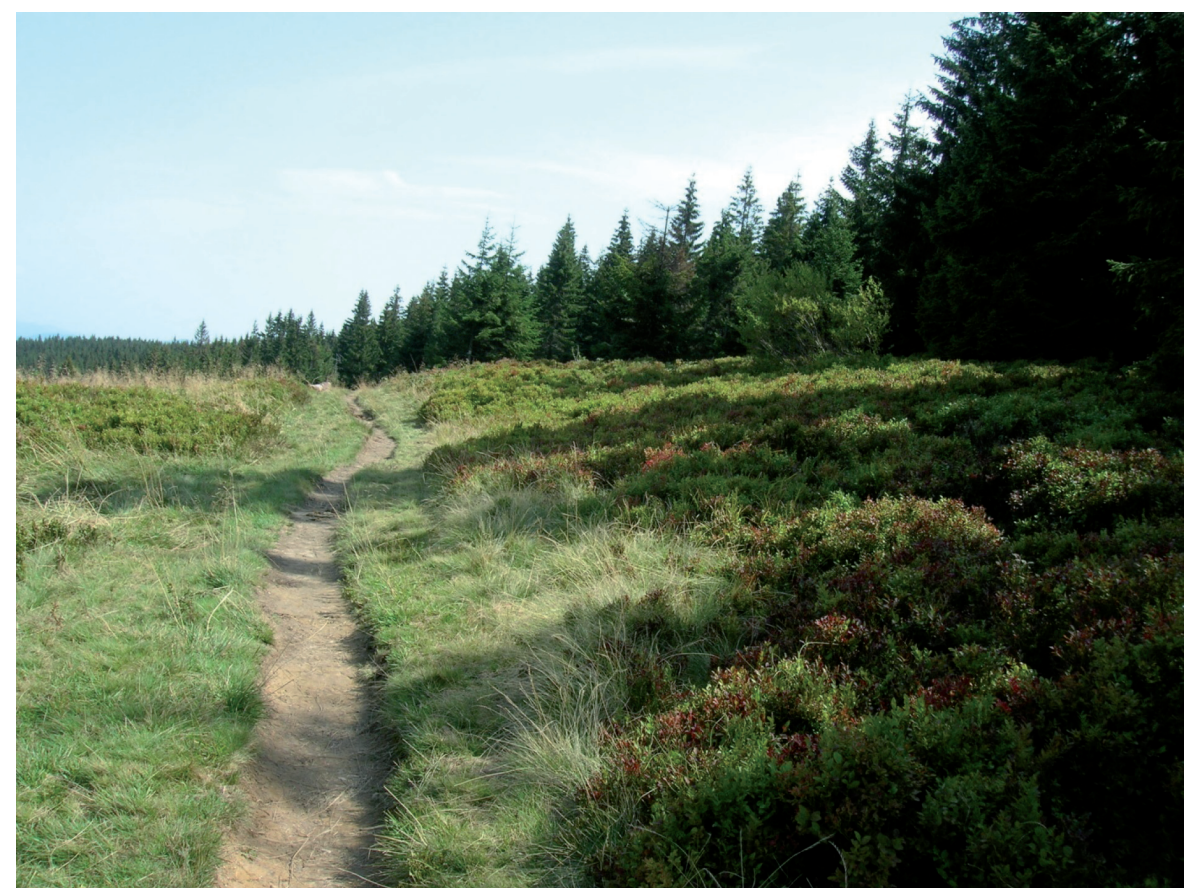

Photo no 2. Bilberries spread into Jaworzyna Kamienicka Glade (photo by A. Sosnowska).

\section{Hala Młyńskie}

The area of the glade has undergone very significant changes which include both reduction of the area as well as its fragmentation. The intensity of the applied efforts is insufficient to retain the present territory. Bilberries (Vaccinium myrtillii) spread from the forest wall, whereas spruce trees (Picea abies) spread throughout the area of the stream head. The existing spruce tree (Picea abies) biogroups situated inside the glade continue spreading (Photo no. 3). 


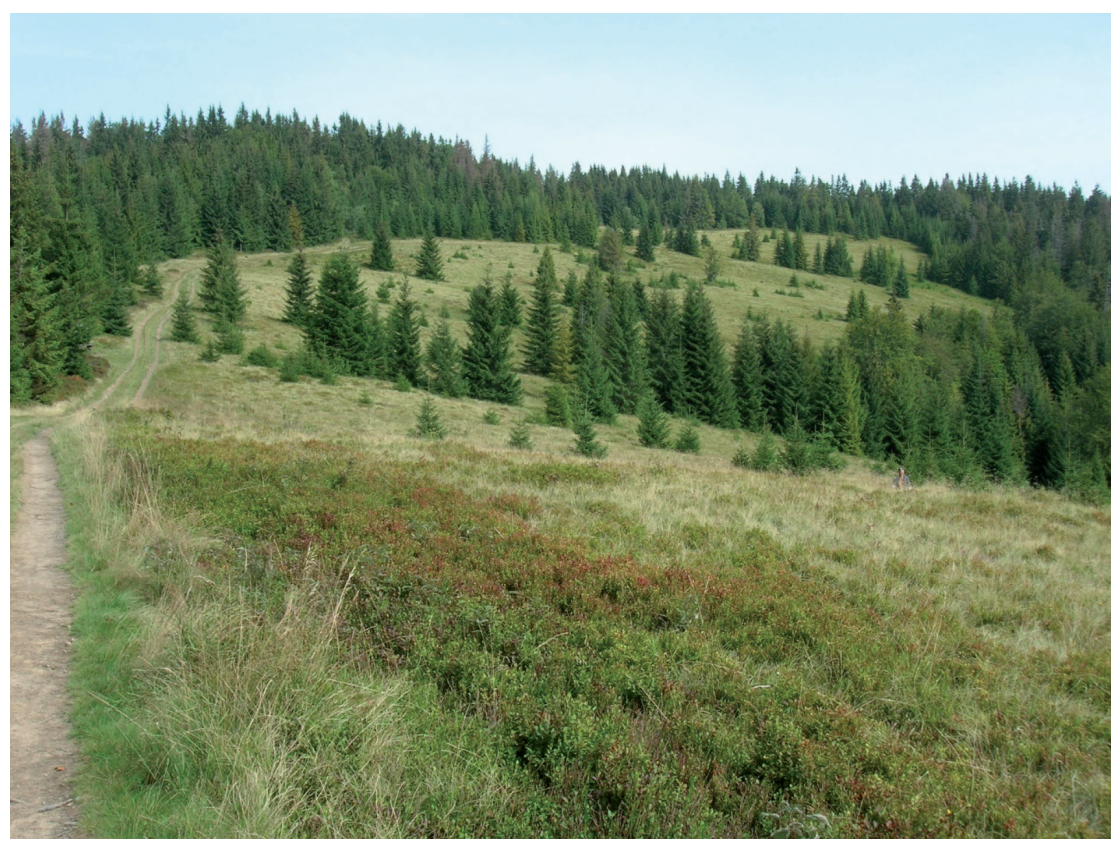

Photo no. 3. Spruce biogrups spread into Hala Młyńskie (photo by A. Sosnowska)

\section{Glades which are not under active conservation}

These glades will be totally overgrown because no conservation activities are being undertaken in the area. For the most part, they are small area glades, to a great degree overgrown with spruce undergrowth (Picea abies) and well stacked bilberries (Vaccinium myrtilii). Some of these glades are situated in areas difficult to reach. In these glades, secondary succession is accompanied by the disappearance of cultural material goods associated with the shed-pastoral economy.

\section{DISCUSSION}

The aforediscussed results coincide with the results of work carried out in the mountain ranges of the Carpathians (Ciurzyński, 2005; Michalik, 1992), including the Gorce Mountains (Michalik, 1995).

The end of working the land in subalpine forest glades led to the expansion of bilberries (Vaccinium myrtilii), allowing for growth of dense patches of bilberries (Vaccinium myrtillii) and wild raspberries (Rubus idaeus). Patches of bilberries and wild raspberry enter mainly from the side of the forest wall and as clumps from inside the glades. This leads to hindering the growth of green plants and allows for quicker growth of trees in the 
glade. In research carried out by the Author, the expansion of spruce trees has been observed in both the lower and higher subalpine forest glades. This is an unfavourable phenomenon because it will lead to an increase in the participation of spruce trees in the tree stand of the lower subalpine forest glade where beech and beech-fir forests trees are typical.

The contemporary subalpine glades are characterized by numerous patches of secondary and transitional plant communities that appear between individual plant communities. This confirms the large dynamics of the spontaneous succession processes which are taking place. According to Michalik (1992), in the Gorce Mountains, $65-70 \%$ of the area of all the glades has undergone partial or total degradation. Michalik (2006) has also confirmed explicitly the unfavourable changes in the flora of vascular plants. Among the species groups, the greatest changes in the number occurred in the case of photophilous alpine species. In addition, numerous animal species, mainly invertebrates, have lost their habitats. The dispersion of perennial tall herb communities, among others, Austrian leopard's bane (AruncoDoronicetum austriaci) and wood cranesbill (Geranium sylvaticum), is observed on the glades.

The secondary succession process has also led to changes in the landscape. The number and area of glades continuously decreases. In the third decade of the 20th century, Stefan Jarosz (1935) made an itemized report of all the subalpine forest glades in the Gorce Mountains. At that time, there were over 350 of them. Currently, in the area of the Gorce National Park, whose territory spreads at the greater part of the Gorce Mountains, there are 110 subalpine forest glades. During several dozen years, their number decreased almost threefold. Because active conservation efforts are carried out in only 59 glades within the Park area, one may assume that that their number will decrease in half.

As research carried out in the subalpine forest glades in the Tatra Mountains has shown (Ciurzyński, 2004a, 2004b), for the most part, the pace of overgrowth depends on the individual characteristics of each glade. Above all, of greatest importance are the surface features and presence of tree biogroups. First of all, succession takes place on glades situated on solidly sloped hills into which trees enter by spring niches. This occurs much slower in flat or slightly sloped areas.

However, it may be concluded from research conducted by Michalik (1992) in the Gorce and Pieniny Mountains, the size of the glade is important. Total overgrowth of large glades ( $>5$ ha) takes about $25-30$ years while smaller glades may disappear in a period of $15-20$ years. It may be assumed, on this basis, that the Gorce Mountain subalpine forest glades, where no conservation efforts are being made and which now are in an advanced phase of succession, will undergo complete transformation within a dozen years. 


\section{CONCLUSIONS}

The changes in biocenosis, landscape and in the material culture heritage have occurred due to leaving off the sheep grazing and subalpine forest glades moving. Such changes depend directly on the intensity of the conservation efforts being made.

Four change trends may be distinguished. The first is associated with cultural sheep grazing. In this case, the surface and environmental characteristics remain unchanged. The second trend is related to a decrease in the glade area. It takes place in an area where conservation actions, comprising mowing every 2-3 years, are carried out. The third trend includes both a significant decrease in the glade area and its fragmentation. This refers to glades where conservation activities are the least intensive. The fourth trend comprises of complete overgrowth of a glade. It is observed in the case of glades where no conservation activities are being carried out.

\section{REFERENCES}

Ciurzyński W., 2004a, Struktura przestrzenna naturalnych odnowień świerkowych na górnoreglowych polanach popasterskich w Tatrach Polskich [Spatial structure of natural spruce restocking on the upper montane belt glades excluded from pasturage in the Polish Tatra Mountains], Sylwan, vol. 7, Warszawa.

Ciurzyński W., 2004b, Wpływ wybranych czynników środowiskowych na dynamikę wkraczania świerka pospolitego na górnoreglowe polany popasterskie w Tatrach Polskich [The influence of some environmental factors on the succession dynamics of the Norway spruce on the upper montane belt glades excluded from pasturage in Polish Tatra Mountains], Sylwan, vol. 9, Warszawa.

Ciurzyński W., 2004c, Wtórna sukcesja na polanach górskich wyłączonych z gospodarki pasterskiej [Secondary succession of forest on mountain glades excluded from pasture economy], Sylwan, vol. 11, Warszawa.

Ciurzyński W., 2005, Dynamika zarastania przez las górnoreglowych polan popasterskich w Tatrach Polskich [Dynamics of forest emerging on the upper montane belt glades excluded from pasturage in Polish Tatra Mountains], Sylwan, vol. 2, Warszawa.

Jarosz S., 1935, Badania geograficzno-leśne w Gorcach [Research on the geography and forests of the Gorce Mountains], Prace Rolniczo-Leśne PAU, 16, Warszawa.

Michalik S., 1992, Zagrożenie i problemy aktywnej ochrony biocenoz polan reglowych [Threat and issues of active conservation of biocoenosis of subalpine forest glades], Parki Narodowe $i$ Rezerwaty Przyrody, vol. 4, BPN, Białowieża.

Michalik S., 1995, Charakterystyka aktualnego stanu zbiorowisk roślinnych, analiza procesu sukcesji i waloryzacja polan reglowych Gorczańskiego Parku Narodowego [Characteristics of the current state of plant communities, analysis of the succession process and valuation of subalpine glades in the Gorce National Park], manuscript, GPN, Poręba Wielka.

Michalik S., 1998, Charakterystyka, waloryzacja i ogólne zasady ochrony szaty roślinnej [Characteristics, valuation and general rules of conservation of plant cover] [in:] Operat ochrony polan reglowych Gorczańskiego Parku Narodowego, typescript, Dyrekcja GPN, Poręba Wielka.

Michalik S., 2006, Skarby gorczańskich polan [Treasures of the Gorce Mountain glades], [in:] Różański W. (ed.) Gorczański Park Narodowy, GPN, Poręba Wielka. 